\title{
THE POSTMODERN CONSUMER: IMPLICATIONS OF CHANGING CUSTOMER EXPECTATIONS FOR ORGANISATION DEVELOPMENT IN SERVICE ORGANISATIONS
}

\author{
A BERNER \\ CL VAN TONDER \\ Department of Human Resource Management \\ Rand Afrikaans University
}

\begin{abstract}
Postmodern society is predominantly viewed as a consumption-oriented society that developed as a reaction to the more traditional, modern society. The observed divide between modern and postmodern societies suggests different consumption patterns and consumer profiles which could have significant implications for service organisations. The discussion contrasted the modern and postmodern eras and societies, and isolated the main characteristics and service expectations of the postmodern consumer. The implications for organisation development (OD) in service organisations, notably in terms of the changes that are required, are highlighted.
\end{abstract}

\section{OPSOMMING}

Die postmodernistiese samelewing word hoofsaaklik as ' $\mathrm{n}$ verbruikersgeoriënteerde samelewing gesien, wat in reaksie op die meer tradisionele modernistiese samelewing ontwikkel het. Die waargenome gaping tussen modernistiese en postmodernistiese samelewings suggereer verskillende verbruikspatrone en verbruikersprofiele wat beduidende implikasies vir diensorganisasies kan inhou. Die bespreking het die modernistiese en postmodernistiese eras en samelewings gekontrasteer en die hoof eienskappe en diensverwagtinge van die postmodernistiese verbruiker geïsoleer. Implikasies vir organisasie-ontwikkeling in diensorganisasies, veral in terme van die veranderinge wat benodig word, word aangedui.

\begin{abstract}
As a result of technology, globalisation and social evolution, change in the $21^{\text {st }}$ century occurs more rapidly than ever, and in a discontinuous way (Robbins, 2002). New forms of production such as "lean production" and "just-in-time" production, diversification of commodities for niche markets, a "flexible" labour force, the concept of "mobile capital" and so forth, have steadily surfaced over the past decade or so and are replacing the long entrenched approach of mass production of standardised goods as well as the forms of labour and work practices required to sustain this approach (Wood, 1996). These practices and changes mentioned by Robbins (2002) and Wood (1996) are testimony to the deep-seated and fundamental change the world is experiencing. Indeed, the world as we know it is rapidly transforming into what is frequently referred to by many scholars as the era of "postmodernism". In order to benefit from these changes, service organisations must effect radical alterations in structure, processes, and methodologies.
\end{abstract}

The use of postmodernism as a concept to describe this phenomenon of worldwide change, has furthermore become widespread in modern societies regardless of whether its existence can be demonstrated (Strinati, 1993). Thomas (1997) suggested that the postmodern/modern dichotomy has been present all along and has been observed by many who, in all probability, have not labelled the phenomenon. It is generally assumed and often implied by scholars (e.g. Takala, 1999) that we are living in a postmodern society - a society characterised predominantly by consumption (Goulding, 2000) where people create a sense of who they are through what they consume (Kacen, 2000). In this new phase or post-industrial age (Goulding, 2000 , p. 837) "...behavioural consistency and orderliness are giving way to fragmentation and market instability..." (Dawes \& Brown, 2000 , p. 90). Market conditions such as slowing growth, market fragmentation, competition and increasing marketing costs are prompting a reassessment of marketing strategies and methodologies (Dawes \& Brown, 2000) and raised questions about accepted models of marketing management (Thomas, 1994) in a postmodern marketplace. According to Arias and Acebrón (2001) most research regarding the consumer and

Requests for copies should be addressed to: $C L$ van Tonder, Department of Human Resource Management, RAU University, PO Box 524, Auckland Park, 2006 business-to-business marketing is based on a modern and not a postmodern environment. It has been argued for example that mainstream marketing is essentially modernist in nature (Brown, 1995) - implying that marketing approaches, and targeted consumer "markets", i.e. the emerging postmodern consumer, are not aligned, and may for example account for the high rate of customer defections (lack of customer loyalty) Dawes and Brown (2000) have observed in the financial services sector.

Traditionally, marketing has always been about consumption (Kacen, 2000) and so several questions are raised about the nature of consumption and consequently consumer behaviour within this unpredictable postmodern marketplace, which, it is suggested, is likely to be more fragmented and equally unpredictable. The literature in fact abounds with references to the postmodern consumer or customer but it is not always clear what is meant or implied by this label.

Despite this lack of clarity, "postmodernism" is viewed as a useful term to interpret and explain present day consumption patterns (Goulding, 2000), and is capable of providing the marketer with practical and meaningful insights into the consumption behaviour of the postmodern consumer (Brown, 1995; Kupiec \& Revell, 1998). This is much needed as the consumer's character and expectations regarding products and services, and consequently the consumer's behaviour, have clearly changed in the "...disconnected and disjointed marketplace of postmodern consumerism" (Dawes \& Brown, 2000, p. 97).

Organisations need to understand how to adapt to this postmodern era, its dominant characteristics, the changes stemming from it, and most importantly, how consumers in a postmodern context perceive value. Woodruff (1997) has for example indicated that customers are now preoccupied with obtaining value, which suggests that organisations should intensify their focus on creating enhanced or new value, but, as Dawes and Brown (2000) indicated, traditional value creation strategies such as new product development (e.g. in the financial services sector) offer limited prospects for gaining competitive advantage. Understanding how the consumer perceives value in this postmodern environment therefore becomes a central survival issue for organisations - at least in the services sector. 
Unfortunately most of the changes and implications of the postmodern era, the postmodern marketplace, and the postmodern consumer have not yet been recognised as most of the research methodologies according to Arias and Acebrón (2001) are still essentially modern in nature. Changes in the world economy and the search for competitive advantage (Woodruff, 1997) suggest that it will be very costly for organisations to ignore the needs and wants of the postmodern consumer as well as the characteristics of the postmodern environment. Given the preceding, Dawes and Brown's (2000, p. 93) advice to financial services retailers/organisations to "...absorb the characteristics of the postmodern consumer" seems appropriate to organisations in the services sector in general. This is a formidable challenge as scholars in some quarters have tended to neglect and at times even reject the critiques of academic research on postmodernism, as people do not really understand the importance of the study of postmodernism and its implications for organisational studies (Kilduff \& Mehra, 1997).

Apart from the need for clarity and therefore information on the role and impact of the postmodern consumer for service organisations, it is also evident that there is an increasing need for research directed at the phenomena of postmodernism and the postmodern consumer, which will inform both the advancement of science, and business practice. In this regard most consumer research to date have been typified as being essentially modern in nature (Arias \& Acebrón, 2001) i.e. research aimed at supporting or informing organisational practices directed at mass markets and stable market conditions. These conditions are of course disappearing in the face of the emergent postmodern environment and as a consequence the misalignment referred to earlier is also prevalent in the usage of (inappropriate) modernist research paradigms and methodologies (Cova, 1996; Dawes \& Brown, 2000; Holbrook, 1997; 1998) with which to explore postmodernism as both a paradigm and a phenomenon.

Notwithstanding the "copious research" on shopper orientations and attitudes (Reid \& Brown, 1996) limited research has understandably been undertaken on consumer behaviour in a postmodern context (Gould \& Lerman, 1998). There is consequently also a growing and clearly articulated need for new and appropriate research methods with which to explore postmodern consumer markets, as well as remain abreast of changes brought about by the postmodern era (Arias \& Acebrón, 2001). There is, finally, also a clear need for more empirical research within the field of postmodernism - in order to judge the merits of postmodernism in the various fields (Fokkema, 1987), as postmodernism has often been the subject of extensive debate at an aesthetic and moral level, but seldom the subject of serious and systematic analysis (Lash, 1990).

In pursuit of clarity on some of the postmodern issues faced by organisations, this discussion is directed more specifically at the following questions:

- Firstly who and/or what are the postmodern consumer and what are his/her service expectations?

- Secondly, from an organisation development perspective, what are the implications of the emerging postmodern consumer for organisations operating in the service industry?

To arrive at answers to these questions, the review will consider and contrast the nature and characteristics of the modern and postmodern eras and societies, patterns of consumption, and the profiles of the modern and postmodern consumer. The implications for service organisations, specifically in terms of the changes they have to introduce and manage in their customer service orientation in order to survive, are considered. The organisation development (OD) and training and development implications of delivering products and services to the postmodern consumer are highlighted for service organisations, and several strategies are recommended.

\section{Modernism and postmodernism}

While the terms "modern" and "postmodern" "...have become common currency in intellectual debates concerning organisational studies" (Takala, 1999, p. 360), they remain shrouded in ambiguity. Neither modernism nor postmodernism are simple or clearly defined concepts (Van Tonder, 1999), which is largely due to the abstract and aesthetic leanings of the concepts (Power 1990). Despite the continued academic debates surrounding the meaning and definitions of modernism and postmodernism, there is an increasing interest within society today to understand postmodernism as a means to growth and development within society as well as a source of continuing profits within organisations (Wood, 1996).

Turning to the meaning of the terms from a more macroperspective, Giddens (1990, pp. 45-46) notes that modernism and postmodernism have essentially been associated with "aesthetic and intellectual movements", whereas modernity and postmodernity have been linked to "changes experienced in social and economic institutions" and "social and economic changes". The era of modernism was characterised as a "progressive and revolutionary movement" unfolding at the end of the $18^{\text {th }}$ century (Burke, 2000), and which took shape in Europe during the 1920s more as an artistic movement (Hassard, 1993). It emphasised the technical rather than the humanistic or social-psychological and, according to Guillén (1997) was anti-romantic, futurist, and functional and rational, and emphasised principles of unity, order, and purity. Modernist society believed among other that progress could only be built on the principles of scientific research, mass production, and processes of industrialisation (Thomas, 1997).

Postmodernism, on the other hand, was introduced into language by Frederico de Onis in the 1930s to describe a minor reaction to modernism (Hassard, 1993). Young artists, writers and critics in the 1960s began using the term postmodernism in reaction to modernism (Featherstone, 1991). In the 1970s and 1980s the nature and character of postmodernism was more visible in the visual and performing arts, architecture, and music, but there was also a sentiment developing that a wider discussion of the term postmodernity, beyond artistic postmodernism, is necessary (Featherstone, 1991). Today postmodernism is an observable and acceptable phenomenon in architecture and design, film and music, art and fiction, poetry and literary criticism, and politics (Gott, 1999).

As the focus of this discussion is not to debate the existence and meaning of modernism and postmodernism per sé, but rather to consider the implications for service organisations, modernism will be assumed to refer to the culture of modernity (Featherstone, 1991) and modernity to the modern age (Takala, 1999). Postmodernism, similarly, will be equated to the emerging culture of postmodernity (Featherstone, 1991) and may be seen as a social, cultural and intellectual movement away from, and following modernism, and which became more prominent during the 1970s. Postmodernism is consequently viewed as a new phase (Goulding, 2000) and a "new paradigm of thought" (Takala, 1999, p. 360). In keeping with Takala (1999) postmodernity will be regarded as the period following the age of modernity.

A clear distinction however has to be drawn between the postmodern society, and the postmodern culture that emerged from the former, and which, in turn, influenced the nature and character of the postmodern consumer. In order to gain an understanding of the postmodern consumer it is necessary to consider and contrast the nature and characteristics of modern and postmodern societies.

Drawing on the perspectives of inter alia Hassan (1987), Gould and Lerman, (1998), Firat and Schultz II (1997), Arias and Acebrón (2001), Takala (1999), Thomas (1997), Strinati (1993), and Woodruffe-Burton, (1998), it is possible to extract and contrast the key features of the modern and postmodern eras. 
TABLE 1

KEY FEATURES OF THE MODERN AND POSTMODERN ERAS

\section{Modern Era}

- Reason embodies unity (rational purposive approach to life).

- Modern nation state, with central government and administration

- Bureaucratic and formal hierarchies

- Industrial and capitalist society

- Industrial mechanisation and mass production, and stable markets and consumption patterns

- Innovation from discovery following attempts at improving/refining the existing.

- Reliance on science and technology.

- A quest for truth through scientific and rational thinking and a focus on facts, causality and fundamental laws (justification through evidence and logic).

- Social division in the form of classes

- Conformity, behavioural consistency and orderliness (adherence to rules \& conventions)

\section{Postmodern Era}

- More intuitive, a focus on meaning beyond reason and consequently reduced unity (splintering and fragmentation). A more symbol-oriented and consumer controlled age.

- Post-industrial state and the breaking down of traditional concepts of economic and social institutions.

- Fluid, fragmented and dynamic institutions (e.g. virtual and network organisations), with a blurring of hierarchies.

- Information society with information explosion and overload (both individuals and organisations). Information is fragmented in nature. Markets are fragmented and unstable.

- Consumer now central to the production process - notions of mass customisation (flexible manufacturing systems). Unpredictable and volatile markets.

- Innovation through new, revolutionary (untested) theories and views (rather than refinements)

- Focus on ideational, appearance and experience.

- Focused on social meaning, and experience driven (phenomenological). Emphasis on the perceptual, hyper-real and symbols (or signification) rather than "real experience".

- Plurality of society with high levels of social diversity. Elevation of the individual at the cost of the community

- Diversity and fragmentation, and liberation from conformity. Recognition and tolerance of differences. Multiculturalism and multi-ethnicity.

- Urbanisation and growth of cities.

Reflecting on the two eras as presented in Table 1 it is evident that the central idea of the modernist era was to bring economic growth and progress to the world at large, through a predominant reliance on scientific (and therefore rational) thinking, mass production, and processes in support of this philosophy. Also clear is that the postmodern era reflects a movement away from the rational towards the intuitive, accompanied by greater fluidity and diversity. Underlying these developments is of course the central and very important shift from an industrial to an information society - facilitated largely by rapid advances in communications and information management technology.

Postmodernism however, should not be interpreted as being only a cultural or artistic phenomenon, but has a much wider meaning and application - as can be seen from the main features of the postmodern society which are contrasted with that of the modern society (Table 2).

By way of summary and following Van Tonder (1999), modern society is basically viewed as a society characterised by the effects of economic and scientific progress on societal structures and cultures - in particular the influence of production, mechanisation and industrial capitalism on, among other, social development (and social differentiation). Postmodern society on the other hand is essentially an information society and, following from the "explosion" of scientific knowledge and the development of new technologies during this era, is further characterised by extensive, rapid, and complex change. This has led to the simultaneous development and co-existence of different forms of culture and society, as well as organisational forms (refer Table 3), which shape individual values and behavioural tendencies.

The observed differences between modern and postmodern societies and those living and working within the respective societies are pronounced and will clearly impact (change or alter) views of consumption, and consequently the consumer profile in the shift from a modern to a postmodern era.

Reflecting on the substantial differences between the modern era, society, and organisational form on the one hand, and the postmodern era, society, and organisational form on the other (Tables 1 - 3), similar differences are to be expected between consumers living in modern and postmodern societies respectively. Through inference it would appear as if the "postmodern consumer", when compared to the "modern consumer", is likely to be a more intuitive, flexible and worldly individual with a distinctive style orientation and consumption approach. He/she would have a more integrative concept of life and work, be tied into the technological conveniences of latter day society, and will be more indefinable in terms of cultural origin and class. This view, that the postmodern consumer differs substantially from the modern consumer, is also evident from the literature - conveyed in Table 4 .

The concept of consumption was clearly altered with the transition from a modern to a postmodern society. During the former, consumption was more purposeful and by and large influenced by the utility value of the specific product or service to the consumer. Consumption was coherent with living in a relatively stable environment where consumers were predisposed towards conformity and consistency, which was further bolstered by the trends and processes of industrialisation and mechanisation. As is indicated in Tables 3 and 4, individualism was unimportant in a modernist culture and consequently differentiation of commodities on grounds other than functionality was limited.

Particularly prominent in the latter day postmodern environment is the notion of compensatory and hedonistic consumption, which supplement and supersede functionality as driving motives for consumption. Whereas compensatory consumption would relate to consumption that fulfils a need, lack or desire that could not otherwise have been fulfilled by the primary source for addressing (fulfilling) the need (Woodruff, 1997), hedonistic consumption refers to consumption that is fuelled by a desire for something different (e.g. experiences and sensations), new and/or pleasurable (Malina \& Schmidt, 1997). These patterns of consumption suggest the very different value systems of modern and postmodern consumers previously alluded to (Table 4), and are bound to prove problematic to product and service organisations. In this regard Dawes and Brown (2000) have for example indicated how customer 
TABLE 2

KEY FEATURES OF MODERN AND POSTMODERNIST SOCIETIES

\section{Modern Society}

Life characterised by realism, authenticity and seriousness.

Linear/predictable living.

Physical conditions and "hard realities" define living.

Laws of nature and physics informed the modern worldview.

Natural world viewed as a source of boundless physical and natural resources

Growth of science and technology as the rational foundation of "truth" and progress.

A belief in absolute truth.

Rationality in the form of facts, evidence, and logic are emphasised.

A sense of unity, derived from well ordered/regulated and integrated social and work structures, and common culture.

Clearly demarcated hierarchies and centralising authorities.

A society where culture and structure were influenced by the impact of economic progress (in particular industrialisation and mass production).

Social development evolving from industrialisation and structured around social differentiation. Social hierarchies were based on occupation and role in the "production" process and self-portrayal was primarily on the basis of occupation and social status.

A common culture established through religion, economy, state and kinship

Society dominated by production, mechanisation and industrial capitalisation in a stable market environment.

"Mass culture" and mass markets.

Essentially a production orientated society.

Consumption patterns were influenced by functionality.

Working environment dominated by industrialisation and manufacturing, with clearly structured job content (e.g. the production line) and low levels of unemployment.

Ordered and stable environment, with low risk and predictable outcomes, requiring disciplined and structured management.
Postmodern Society

Life characterised by pastiche - irony, parody, imitation/mimicry, humour, and the "wink of the eye".

More complex living.

Hyper-reality: A world of imagery e.g. cyberspace, virtual realities and computermediated environments where simulation and representation are more important than reality. The media significantly influences and defines the individual's sense of reality.

Laws of grammar and semantics inform the postmodern worldview. Antifundationalism dominates - boundaries of established categories and stereotypes are dissembled and cross-fertilisation is promoted (e.g. in the domains of science and technology).

Natural world has limited natural resources and heading for a catastrophe as a result of current consumption rates.

Explosion of scientific knowledge but mass disillusionment with science and a loss of confidence in the philosophy of progress through rational, purposive means.

A focus on meaning beyond scientific fact and truth, which is embedded in a broader context - a strong focus on the totality of a situation. Absolute truth is rejected as meaning is constantly changing. Social meaning is substantially influenced by form and style.

An emphasis on symbols, appearance, and style at the expense of substance and content (a "designer ideology").

Fragmentation (lack of continuity) - as a result of unwillingness to conform and accept a single idea or product, coupled with a constant search for stimulation through events and images.

Dedifferentiation: The boundaries defining the identity of individuals and institutions have become blurred, shared and mixed (e.g. between high and low culture, training and education, politics and show business).

A complex society reacting to the salient features of the "modern society", and which is characterised by overwhelming amounts of information, and rapid and continuous change.

"Tribes" develop around interests, preferences and lifestyles, and are replacing social classes. Social class defined by birthrights or accumulated wealth, is becoming irrelevant. Self-portrayal through products that are consumed and how the individual presents him/herself. Individuals create, transform, and reconstruct their sense of identity through the meaning conveyed by tangible "marker" products (form and style).

No longer a common culture - rather a multiplicity of cultures, where pluralism and diversity are dominant features and reflect the change in value systems.

New forms of technology, and flexible and real time manufacturing systems in volatile and unpredictable marketplaces. Global competition combined with rapid technological change results in a lack of continuity.

"High culture" with expanded range of product offerings and product categories, "mass customisation" of products in micro and niche markets (essentially a fragmented market)

Essentially a consumption (consumer-driven) society.

The consumer will consume the images/signs for what they represent, rather than purchase a product for its usefulness.

Growth of the service sector with increasing levels of unemployment, and alternative forms of work e.g. telecommuting, working from home, job sharing and part time work, arising out of the decline in the manufacturing environment

Disorder and chaos characterise the business environment, creating higher levels of risk and requiring flexible and adaptable management (change-competent).

TABLE 3

MODERnIST AND POSTMOdernist ORgANISATIONS (ADAPTED From VAN TONDER, 1999, P. 32)

Modernist organisation characterised by...

- Rationality.

- Highly differentiated organisations (the bureaucracy is the classic form of the modern organisation). Planning is a core activity

- Efficiency and administrative control

- Hierarchical control

- Organisation charts

- Official positions, job descriptions, distinctive titles, and time sheets

- A view of employees as cost factors.
Postmodernist organisation characterised by...

- Organisational forms still ill-defined (but virtual and network organisations are illustrative).

- "De-differentiated" form.

- Avoidance of hierarchy.

- Flat structures (3 to 4 symbolic levels) (anti-structural in orientation).

- Flexible specialisation - inherently an unstable form. Responding to change is the core activity.

- Niche based marketing strategies and multi-skilled, craft oriented workforce.

- Self management and self managing work teams

- Direct, informal relations and open access to executives

- Access to all information.

- A view of employees as partners/stakeholders. 
TABLE 4

\section{THE MODERN AND POSTMODERN CONSUMER}

Modern consumer

Consumption was viewed as being more functional and rational and therefore meaningful, consistent and clear in its purpose.

Viewed as a passive target group.

Essentially conforming and traditional, and consequently homogenous in needs.

A wholly analytical and rational being and in terms of consumption and buying behaviour, essentially considered an "information processor".

Was predictable and clear in his/her service expectations.

Preferences were gender-specific and consumption patterns followed from clear role stereotypes (associated with specific gender) - underscoring the sense of collectivism and conformity.

Focused on a singular lifestyle concept, founded on the modern values of orderliness and consistency.

Self-portrayal anchored strongly in the individual's occupation and social status

More susceptible to mass-produced products and services (mass markets) that are useful in day-to-day living.

Loyal to a firm, brand, or product.
Postmodern consumer
Consumption is viewed as being more hedonistic, self-affirming, and compensatory.

More active, in constant search of stimulation through events and images and, as a consequence, has more power than his/her modern predecessor. Referred to as "Simulated pseudo-explorers in virtual pseudo-realities..." (Thomas, 1997, p. 56). Global, non-conforming, and unpredictable (lacks depth and continuity). Generally open to new experiences and have few preconceptions about service. Many-faceted consumer that has become increasingly sophisticated and is likely to rely on own ability to seek value. Experience and pleasure are important. More humanistic and tolerant.

May be unable or unwilling to express the meaning they seek and often have only a vague preconception of what is desired.

More individualistic in preferences and needs (genderless/with a blurring of gender stereotypes). Individual taste(s) and meanings are important, and consequently, individuality and sense of style is displayed through choice of goods/products and services ("assemblage" - Featherstone, 1992, p. 63). (An "autonomous micro-particle" - Baudrillard, 1996, p. 106).

Engaged in multiple lifestyles and subscribes to multiple and often highly incompatible value systems. Is consequently immune to incoherence and accepts and may even appreciate and enjoy discontinuity.

Self-portrayal and identity more prominently through imagery (symbolic value) created through consumption. Increasingly seeking, developing, or affirming personal identity through symbols (products and services) consumed.

Appreciates individual and unique characteristics of products and services and places an emphasis on the spectacular, the popular, the pleasurable and that which is immediately accessible.

Avoids commitment and exercises freedom to move where choice or whim dictates (an unencumbered self - Gould \& Lerman, 1998). defection levels in the UK financial services retail sector (more pertinently banks and building societies) are increasing. Apart from the fact that this may be indicative of the changing value placed on loyalty by modern and postmodern consumers respectively, Dawes and Brown (2000) argued that this is due to a reliance on established marketing practices that are essentially modern in nature and consequently inappropriate for a postmodern marketplace.

The differences in consumption patterns associated with modern and postmodern consumers are pronounced and could have far reaching implications for service organisations. Depending on whether the service organisation is serving a predominantly modern or postmodern consumer sector, the organisation's product/service strategies, marketing approaches, supporting operational technologies and capacities, and management philosophies will differ substantially. Considering also that some service industries are in fact still essentially modernist in their market approaches (Brown, 1995; Arias \& Acebrón, 2001) and may be serving sectors consisting largely of postmodern consumers, the likelihood of reduced operational performance, non-competitiveness and loss of market share for these organisations is substantially increased.

Turning to the consumer, it is observable that the modern consumer valued the functionality and utility value of a specific product or service, and the ability of this product or service to solve his/her "problem", while the postmodern consumer is less concerned with this. He/she is focused on a more intangible "problem", that of building a sense of self or identity in a highly dynamic, complex and fragmented society, and is consequently more interested in the symbolic or cultural value that a specific product or service projects, and the image it holds, rather than its content value. Loyalty to a brand (as with modern consumers) will not be a base for competing in the postmodern marketplace.

The postmodern consumer has a strong sense of immediacy and expects services/tasks to be done immediately. In addition, he/she expects the product and service provider to do much more than that which is conveyed by the linear message received from the service provider. For example, should the request be to change all personal contact details, the expectation is that the service provider will do so within the consumer's timeframe (which is likely to be more demanding), and not in accordance with company procedures and traditional company established timeframes. As a result of the information-rich environment in which they have grown up, they will have an exceptional demand for facts, and if something cannot be done immediately, they would need to know why. Should they believe they are not getting the facts from the company, the company will immediately lose credibility and face value (MapActive, 2000).

The postmodern consumer's character and service expectations can accordingly be summarised as follows: He/she is a consumer who:

- Creates and builds his/her identity through the products and services he/she consumes - more specifically the intangible value the product or service holds. All products or services are consequently evaluated on the symbolic or cultural value they project, and less so in terms of the functional value it holds.

- Is highly individualistic in his/her preferences for the consumption of products and services.

- Is not loyal to any product or service (will avoid any commitment), will not conform to pressure for brand loyalty either, and will exercise the freedom to move where choice or whim dictates.

- Asks for immediate gratification (need satisfaction) and consequently immediate service rendering and responsiveness by the service provider.

- Focuses on facts. Should the service provider not be able to provide this essential service, the provider will lose credibility and the consumer will search for a provider that can fulfil this need.

- Is information and information-technology oriented.

- Expects more from the product or service than is conveyed by marketing of functionality. 
- Subscribes to many lifestyles that are often accompanied by highly incompatible value systems.

- Does not conform to the traditional values of society and is unpredictable in his/her behavioural patterns.

The postmodern consumer lives in a world filled with "doubt, ambiguity and uncertainty" (Thomas, 1997, p. 58) and it is in this context that organisations need to comprehend and satisfy the needs and wants of the consumer, if they wish to survive in the postmodern marketplace.

\section{Locating the postmodern consumer in time}

While it is difficult to locate the modern and postmodern consumers in a specific timeframe, because of the ambiguous and ill-defined nature of the eras, scholars tend to concur that postmodernism emerged more visibly from the 1970s onwards. Prior to this, modernist perspectives on the consumer were still readily subscribed to and company performance tended to support this orientation, which by and large recognised only mass markets and mass commodification. The practical implications of the different consumer profiles surfacing from the modern and postmodern eras can be further understood if they are related to the successive generations that emerged during the same timeframe.

In this regard Washburn (2000) identifies the "G.I. generation" (born between 1901 and 1925), the "silent generation" (born between 1926 and 1945), and more prominent and relevant to the modern and postmodern discussion, the so-called "baby boomers" (born between 1945 and 1964), "generation X" (born between 1965 and 1981) and the "Net-", "Y-", or "digital generation" (born between 1982 and 2003). While these generations do not have exact boundaries and many exceptions are in evidence, overall trends and directions for these generations are visible (Washburn, 2000).

The "GI" generation who lived through the great depression and fought in World War II, is credited with the basic shape of current societal institutions (civic, religious, fraternal, etc) (Washburn, 2000). They subscribed to civic virtue and upward mobility and had a characteristically strong adherence to the collective and camaraderie, which, apart form the date range, place this generation squarely in the modernist fold. The "silent generation" who followed, admired the GI generation and were good caretakers of the "better" world they inherited from their predecessors and consequently had no desire to challenge the status quo. According to Washburn (2000) they demonstrated a strong allegiance to a system of principles such as law and order, patriotism and faith. As a generation it similarly finds itself enacting the lifestyle and values of a modern society.

The "baby-boomers" was the first post-war generation (born between the years 1945 and 1964) and is considered the best educated ever. The generation derived its name from its sheer numbers, which provided it with the dominant share of the current $(26.5 \%)$ and future world population - estimated to be around 25\% in 2010 (Silver, 1999). Their pursuit of predictability, consistency, economic security, and a prosperous future (Silver, 1999) as well as their strong work drive, commitment to long term objectives, and very high aspiration levels, bear the signs of a modernist society. Their distrust of traditional values, authority, and institutional principles, their need for instant gratification, and their reluctance to trade personal pleasures for the sake of the group (Washburn, 2000), suggest early leanings towards a postmodern philosophy and lifestyle. For this reason this generation can be regarded as the first to begin the transition from a predominantly modern to a predominantly postmodern era.

Subsequent generations and generation " $\mathrm{X}$ " in particular (also known as the thirteenth generation - Washburn 2000) have progressively shed this traditional work ethic and life orientation in favour of creative and entrepreneurial self-reliance, informality, scepticism, independence, and a fairly casual stance towards authority (Finklestein, 2001). This generation has had extensive exposure to technological innovation and was heavily influenced by the media, and access to an expanded global network of cultural influences, from which they borrow freely in terms of language, fashion, music and food (Silver, 1999). This extensive exposure to information has made it a particularly sophisticated "market" generation. They have a strong sense of immediacy, are wary of institutions as they feel they lack authenticity and realism (Washburn, 2000) and are in constant search of excitement (Silver, 1999). Similarities observed between the generation X profile and the postmodern consumer profile highlighted in Table 4, indicate that this generation has bridged the modern and postmodern eras and is largely postmodern in nature.

Generation " $\mathrm{Y}$ ", similar to its predecessor, generation " $\mathrm{X}$ ", is characterised by ambition, individualism, optimism, cynicism and pluralism (Young \& Gautier, 2001). This is a generation that places very little value on tradition and have an equally limited faith in the way things were done in the past (Young \& Gautier, 2001). According to these authors generation $Y$ is highly individualistic and constantly seeking self-expression. Merrick (2000) referred to generation $Y$ as the "techno savvy" generation, as approximately $71 \%$ of its "members" have access to the worldwide web. They grew up with portable computers, the email system, and instant communication, and consequently have no memory of a time when technology did not exist (Washburn, 2000). As a result, they are used to instant information exchange, and fast, efficient client service. Unlike earlier generations that allowed factors such as aspirations and stability to define their view of work, this generation is more concerned with ongoing training and development, support, a good working environment, etc. The generation " $\mathrm{Y}$ " profile fits the profile of the postmodern consumer (Table 4) exceedingly well and suggests that this generation is firmly located in a postmodern context. This broad alignment is supported by the general time parameters suggested by authors dealing with postmodernism and generations respectively.

In Figure 1 the modern and postmodern eras are overlaid on that of the different generations as they superseded one another during the past couple of decades.
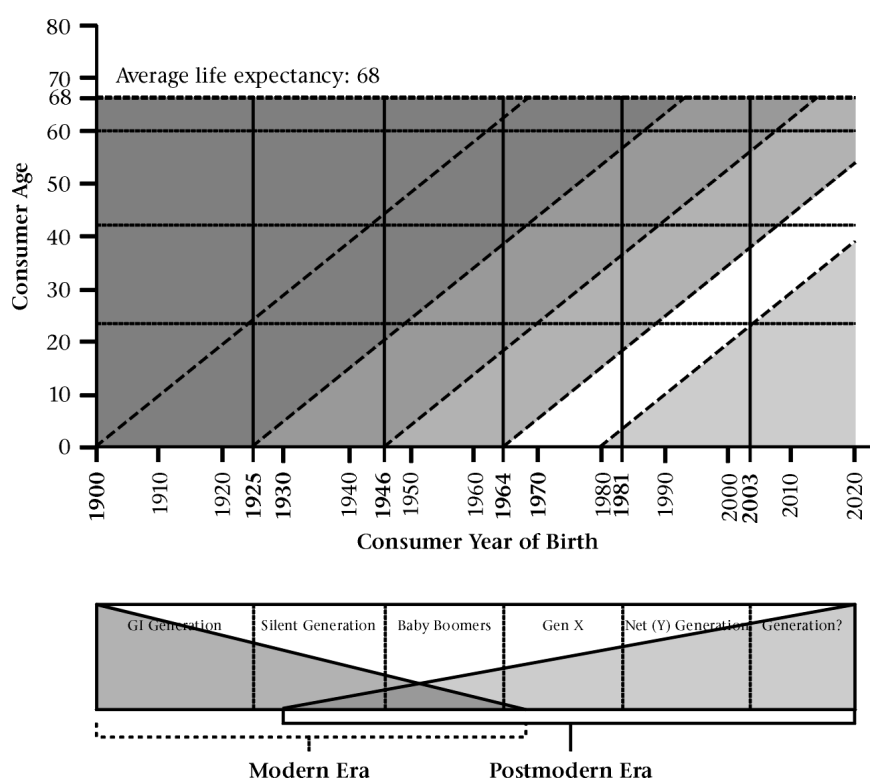

Figure 1: Modern and postmodern eras and successive generations

Reflecting on the alignment of datelines (Figure 1), it is proposed that generation " $\mathrm{X}$ ", and in particular generation " $\mathrm{Y}$ " or the "digital generation" are more clearly "products" of the postmodern era. They more closely approximate the 
"postmodern consumer", with generation "Y" effectively the first bona fide postmodern consumer.

While Figure 1 suggests broad time parameters in which the postmodern consumer can be located, and that he/she has been around since the early to mid 1980s, it also raises several questions about where organisations might be located in the modern-postmodern framework? More specifically, does the age and value systems of an organisation's key decision makers, or the dominant age groups and generations represented in an organisation locate the institution in a predominantly modern or postmodern context? Or, does the majority of the work force in terms of age and value sets locate the organisation in a predominantly modern or postmodern era? Do the majority of the institution's consumers, by virtue of age and generation (and consequently value set) resort in a predominantly modern or postmodern category? The literature seems to suggest that postmodern consumers will increasingly replace modern consumers, but that organisations unlike consumers still appear to lean more towards modernism.

The postmodern consumer, as an artefact of the transition from the modern to the postmodern, signals the need for changes in the marketing and service approaches of organisations. The change implications for organisations in fact extend beyond this. In this regard it has been asserted that the rise of postmodernism signifies a shift towards a view that recognises organisations as being less cognitive and more intuitive, ideational and irrational (Van Tonder, 1999). This shift would for example lead to the development of organisational forms that are more capable of servicing the postmodern consumer with his/her altered preferences and consumption patterns, such as those described in Table 3. Using the two organisational forms (Table 3) as a frame for categorizing current organisations in the service sector, the likelihood is strong that organisations will be found wanting, that they in reality have been slow to make this transition, and that most are still essentially modernist in nature. The problem however, is as Clegg (1994) indicated, that those organisations that are trapped in modernist organisational forms will systematically be outflanked by leading edge organisations that have become more postmodern in nature.

The possibility of misalignment between organisations in terms of their focus, value set, approach to the market and supporting operational capability on the one hand, and the emerging postmodern consumer with his/her altered lifestyle, consumption patterns and "value" expectations on the other, is very real and suggest that organisations consider strategies for surviving in this fragmented and disjointed postmodern marketplace.

\section{Implications for service organisations}

Given the preceding context, what are the immediate implications for service organisations and more specifically, what are the organisational change (i.e. the organisation development) and capacity requirements (i.e. building employee competence through training and development) if organisations are to "absorb" the features of the postmodern consumer (Dawes \& Brown, 2000)?

It is firstly possible for service organisations not only to survive, but to benefit from the changes and opportunities brought by postmodernism, but they will have to effect radical changes to philosophy, structure, processes, and methodologies with regard to customer service, products and services on offer, and to a number of related organisational functions. The risk associated with major change and the adverse impact of ill-conceived and managed change initiatives suggest that these changes be well planned. Organisational development initiatives that will have to be considered in order to survive in, and capitalise on the postmodern service market have to focus carefully on the needs and wants of the postmodern consumer, and need to incorporate the relevant stakeholders within the service organisation to ensure organisation-wide ownership and commitment to the change. Enduring change with minimal disruption to existing operations and employee morale, suggest a collaborative and shared "problem solving" process, using some of the wellestablished behavioural science technologies available for arriving at solutions that will benefit both the organisation and the employee. Action research and the currently more popular appreciative inquiry as process methodologies may, in a generic form, prove useful as overarching frameworks for managing the transition from a misaligned to a more aligned organisationcustomer position. Naturally, these changes and the transition to a more aligned organisation - consumer position, need to be driven by top management.

Within the process-oriented framework of organisation development sketched above, several implications and consequently recommendations can be made. In general, the analysis of the changing consumer profile and the observation that organisations have been slow to match the postmodern consumer, offer room for several interventions through which closer alignment between organisation and consumer can be secured.

Implicit in the modern-postmodern framework as portrayed, is the need to return to organisational self-analysis, as starting point for establishing the degree of alignment between organisational philosophy, focus, operational thrusts, consumer orientation and the nature and range of products or services on the one hand, and the profile and expectations of the dominant consumer sector to which the organisation directs its services on the other hand. This requires a reappraisal of consumer patterns, desires, and the fundamental consumer profile of the dominant consumer segment to which the organisation targets its products and services. At the same time it should be recognized that traditional methods for sampling consumer needs have been criticized extensively and it is generally accepted that alternative research methodologies need to be employed in order to accurately determine and define the postmodern consumer's profile and needs (Cova, 1996; Dawes \& Brown, 2000; Holbrook, 1997; 1998).

A second major implication emerging from the modern-post modern framework, is the nature and extent of organisational change necessitated in the event of misalignment (for which a high probability exists) given the view that most organisations have tended to be "trapped" in a modernist fold when it comes to marketing.

Apart from the suggestion that service organisations need to return to careful measurement and monitoring of self and client profiles, they need to establish and expand the organisation's internal capability to monitor and respond appropriately to the postmodern consumer. The ability to successfully "shadow" the postmodern consumer is likely to prove difficult to establish in view of their fluid, short term, and flighty orientation, coupled to their need for immediacy, and meaning beyond the functional (e.g. the symbolic and cultural image projected by services), but also their lack of consistency and loyalty. It would imply that service organisations firstly introduce and establish an appropriate postmodern customer mindset with a commensurate sense of urgency (responsiveness) in the organisation, and thereafter the capability to sample and register appropriate information in a reduced timeframe - given the postmodern consumer's paradigm (born into a hyper-fast computer-mediated and electronic information-rich environment). It secondly implies that the institution entrenches the capability to modify/alter and deliver customised products and services to the erratic postmodern consumer. The latter in turn necessitates an operational capability built around innovation, effectiveness, and efficiency. The organisational changes implied for an organisation committing to the postmodern consumer is therefore comprehensive, extending beyond its focus, internal capability to deliver products, and the design and packaging of products, to include the critical ability to obtain and manage information from a dynamic and unpredictable consumer segment. 
Arias and Acebrón (2001) have suggested that a postmodern manager is emerging in response to the changing, multi-faceted, and ill-defined managerial situations that arise and the demands that new, shifting and multiple realities are posing to companies. They argued that this manager is essentially characterised by non-linear, contingent, and discontinuous thoughts and practices. Either way, traditional management approaches and strategies will not suffice in a service organisation that attempts to remain close to a (changing) consumer profile.

More specific implications are that the traditional "front-office" and customer interface departments need to be recognized as critical receptors and instruments in the continued successful functioning of any service organisation. Not only should these functions and there employees be appropriately focused and orientated to the emerging postmodern consumer profile, but they should also be empowered with relevant skills and competencies that will enable the selection and registration of relevant information (about consumer desires and preferences) in a timely manner. This is important, as it will allow the institution to respond quickly and effectively to changing consumer requirements. Skills required in this domain typically include enhanced relationship skills, information gathering and processing skills, and communication skills. It also implies expanding the "receptor network" as embodied in the customer service and front office functions that deal with customers on a direct face-to-face basis. Call centres, the internet and ecommunication are not only effective as trading instruments or communication vehicles for the organisation, but particularly useful "receptors" for capturing the postmodern consumer's consumption needs and preferences, but also as "tools" for ensuring that the immediacy aspect of their needs could be addressed (e.g. through online shopping and internet banking).

Indeed, the traditional roles of employees within the organisation need to be expanded with enhanced customer awareness and sensitivity, and a "data sensitive" orientation. This should be supplemented with internal systems and methodologies that will be capable of capturing this information and translating it into product/service design and packaging outputs in as short a cycle time as may be possible. Implicit in this requirement, is the underlying "learning" orientation and learning culture that is indicated, as well as the internal operational capability to rapidly reconfigure systems and technology in order to deliver to a consumer that is predominantly short term, flighty and non-committal in his/her preferences and likely to be more illogical in his/her consumption requirements.

An increasing flow of information that is not only quantitatively but also qualitatively better, is critical to the creation of the underlying rapid response capability needed to respond effectively to the postmodern consumer. Apart from integrating the development of a learning culture in a systematically managed change process, the emergence of the postmodern consumer also suggests a number of basic competencies that should not be neglected and in fact should be over trained. These relate to multiskilling in the general sense and more specifically to enhanced relationship skills such as customer liaison, listening, constructive relationship building, and various forms of communication, data gathering and data processing skills. Innovative problem solving (i.e. lateral thinking) supported by a general attitude predisposed towards listening and synthesizing large amounts of customer data, become equally important.

The product-to-market cycle time and the turnaround time for systems adjustment, become critical achievement and competitive dimensions. Key functions that will influence and enable the adjustment of the organisation to a changing consumer profile are the research and development (R\&D) function, the information technology (IT) function and the management function in general. Organisation development efforts should consequently direct its initial focus to these functions as core enablers, and as drivers of organisational change towards greater organisation-customer alignment.

Large-scale and comprehensive interventions (French \& Bell, 1999) such as the "getting the whole system in the room" interventions may be more appropriate initially to orientate the organisation to the changing demands of a progressively more postmodern consumer and a postmodern environment. Large scale interventions of this nature has the benefit that the same "message" is spread virtually immediately to the whole system, which is necessary if the implications for internal operational efficiency, and the reconfiguration of operational capabilities in support of a business more closely aligned with the postmodern customer, is to be brought home rapidly.

Traditional organisation development methodologies are however also clearly suggested for the transition necessitated by the change from an organisation serving a modern consumer to an organisation serving a postmodern consumer. This is necessary as a large number of major organisational change processes that had to bring about organisational change of this nature and magnitude have not produced the desired results (see for example Pascale, Millemann \& Gioya, 1997, in terms of the implementation of improvement programmes, and Ross, 1997, in terms of reorganisations). The latter is due largely to organisational change efforts that are essentially structural in nature such as Business Process Reengineering (BPR) and the Total Quality Management (TQM) movement, that have been elevated to an absolute level with minimal consideration for the changing generations with their accompanying value structures. The non-humanist nature of business interventions such as these essentially ignores the changing consumer profile and consumption patterns. These methodologies are inadequate for dealing with the changes prompted by the postmodern marketplace.

Underlying the above discussion is the salience and importance of time as a critical performance dimension for success in the postmodern era - a criterion underscored by Arias and Acebrón (2001). The increasing use of call centres as a means to address the postmodern consumer's need for immediacy is an indication of how some organisations are attempting to adapt to the postmodern environment. The postmodern consumer's request for simple, fast, and efficient service will become a way of life for the consumer of the future. Through for example 24hour service offered in Call Centres, organisations are rising to the competitive challenge of time as embodied in the postmodern consumer's need for immediacy. Central to an effective and efficient service is an adequate information technology system that is well managed - particularly in areas such as administration and client information (e.g. personal particulars, transaction history, etc.). Successful servicing of the postmodern consumer will depend heavily on the ability of organisations to upgrade and adjust their service ability through information technology.

Neither the modern and postmodern eras nor the different generations can be absolutely separated in time as the transition from one era to another, and from one generation to another has been, and remains, a gradual (evolutionary) change process. The three consumers i.e. the "baby boomers", "generation X" and the " $\mathrm{Y}$ " or "digital generation", at this point in time in fact share the marketplace simultaneously and, because the extent of their exposure to the modern and postmodern eras differ, it would be impossible to argue that the consumer market is only modern or postmodern in nature. An organisation could in fact be marketing to modern, and postmodern consumers, as well as consumers that are in transition between a modern and postmodern context (e.g. the "baby boomers"). In the current timeframe, and given the average life expectancy of a consumer (68.3 years according to Bradford \& Dorfman, 2002), 
organisations are likely to market to a consumer mix representing the "silent generation" (in the age group 58 to 68 years), the "baby boomers" (aged between 42 and 58 years), "generation X" (varying between 25 and 42 years) and "generation Y" (between 0 and 25 years of age) - each with their own values and expectations. In terms of the modern and postmodern dichotomy, these generations simultaneously represent service expectations of the modern and postmodern societies as well as those caught up in the ambiguity of the transition from the one to the other. This reaffirms the need for organisations to critically reassess their market segments also in terms of the modern and postmodern dichotomy, in order to establish the dominant category of consumer service expectations with which they have to contend (refer Figure 2).

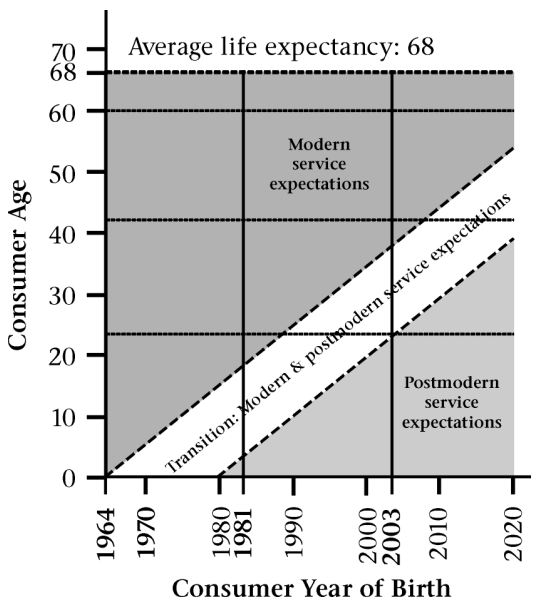

Figure 2: Framework for establishing dominant service expectations

\section{CONCLUSION}

In view of the increasing prominence of the so-called postmodern consumer, but also the limited and fragmented information available on the subject, this study firstly set out to distil a profile of the postmodern consumer from the available literature, and secondly to consider the change and organisational development implications for the global service sector.

Scope constraints prevented an extension and further contextualisation of the profile of the postmodern consumer to different application contexts, but the study has attempted to consolidate a large part of the ambiguous road towards empirically oriented studies of the postmodern consumer. In this regard the extracted profile of the postmodern consumer can be subjected to empirical testing yet also serve as a platform from which empirical testing of hypotheses and assumptions in respect of the postmodern consumer and his/her preferences can be launched.

The paradigmatic shift from the modern to the postmodern has profound implications for organisations and organisational product and service offerings, and consequently for organisational strategy, structure, supply chain technologies and employee competence profiles. The implied cost to organisations of the change indicated by the emergence of the so-called postmodern consumer (but also the risk of non-change) is substantial and suggests that a high priority be placed on research that further clarifies the scope, nature, and impact of this emerging consumer group. In this regard numerous avenues for future research are indicated which include, perhaps more urgently, the construction of operational definitions and measures with which to empirically test and validate the profile of the postmodern consumer. Secondly, the relevance of the postmodern consumer's profile in the differing contexts of a developing and a developed world (and those areas where they collide) indicates research opportunities worthy of further pursuit. The application of the modern-postmodern consumer dichotomy in third world contexts suggests many complexities particularly where representatives of the different consumer categories share a common marketplace. This in turn highlights several very useful avenues for further research that would have an immediate bearing on organisational practices.

Finally, and most importantly, organisations may already experience the transition from a modern to a postmodern consumer environment as a difficult and confusing period at an operational level, yet may be unaware of the underlying and fundamental change that is taking place in the consumer profile. They may be similarly unaware of the emerging (and enduring) service expectations of the postmodern consumer and the change implications for organisations. Organisations consequently have to recognise the demands of serving the different consumer categories, while preparing for the postmodern consumer's increasing prominence in the market. In this regard those organisations that attempt to reconfigure themselves for servicing the postmodern consumer will reduce risk and may well increase the loyalty of aging modern consumers rather than alienating them. The converse may be true for organisations that remain focused on the modern consumer and defer on adjusting for the postmodern consumer's service expectations.

\section{REFERENCES}

Arias, J.T.G., \& Acebrón, L.B. (2001). Postmodern approaches in business-to-business marketing research. Journal of Business and Industrial Marketing, 16 (1), 7-20.

Arnould, E.J., \& Price, L.L. (1993). River magic: Extraordinary experience and the extended service encounter. Journal of Consumer Research, 20 (June), 24-45.

Bradford, D., \& Dorfman, A. (2002). The State of the Planet. Time South Pacific, 34, 37. Available: EBSCO Host: http://wwwsa.ebsco.com/home/default.asp/. AN 7257934 (Accessed 19/09/2002). Password required.

Brown, S. (1995). Postmodern marketing. London: Routledge.

Burke, B. (2000). Post-modernism and post-modernity. Available at: http://www.infed.org/biblio/b-postmd.htm. Last updated (20/06/2001). Accessed (22/10/2001).

Clegg, S.R. (1994). New organizational forms. In C. Hardy, Managing strategic action: Mobilising change concepts, readings and cases. London: Sage

Cova, B. (1996). The postmodern explained to managers. Business Horizons, 39 (6), 15-24.

Dawes, J., \& Brown, R.B. (2000). Postmodern marketing: research issues for retail financial services. Qualitative Market Research: An International Journal, 3 (2), 90-98.

$\mathrm{Du}$ Plessis, F. (1990). Introduction. In P.J. Du Plessis (Ed.), Consumer Behaviour: A South African Perspective. Halfway House: Southern Book Publishers.

Featherstone, M. (1991). Consumer Culture and Postmodernism. London: Sage

Featherstone, M. (1992). Consumer culture and postmodernism. London: Sage.

Finkelstein, B. (2001). Hiring Generation X. Broker Magazine, 3 (3), 9 (1p). Available: EBSCO Host: http://wwwsa.ebsco.com/home/default.asp/. AN 4837076 (Accessed 20/05/2002). Password required.

Firat, A.F., \& Dholakia, N. (1995). Marketing in a post modern world. European Journal of Marketing, 29 (1), 40-57.

Firat, A.F., \& Shultz II, C.J. (1997). From segmentation to fragmentation. Markets and marketing strategy in the postmodern era. European Journal of Marketing, 31 (3/4), 183207.

Fokkema, D. (1987). Concluding observations: Is there a future for research on postmodernism? In M. Calinescu \& D. Fokkema (Eds.), Exploring postmodernism: Selected papers presented at a workshop on postmodernism at the XIth International Comparative Literature Congress. Amsterdam: John Benjamins Publishing Company. 
French, W.L., \& Bell, C.H. (1999). Organization Development: Behavioral science interventions for organization improvement, $6^{\text {th }}$ edition. Upper Saddle River, NJ.: PrenticeHall.

Giddens, A. (1990). The consequence of modernity. California: Stanford University Press.

Gott, R. (1999). It's irony, guv. New Statesman, 129 (4425), 55(3p). Available: EBSCO Host: http//www.search.epnet.com/. AN 1642901 (Accessed 10/05/2001). Password required.

Gould, S.G., \& Lerman, D.B. (1998). "Postmodern" versus "longstanding" cultural narratives in consumer behavior: an empirical study of NetGirl online. European Journal of Marketing, 32 (7/8), 644-654.

Goulding, C. (2000). The commodification of the past, postmodern pastiche, and the search for authentic experiences at contemporary heritage attractions. European Journal of Marketing, 34 (7), 835-853.

Guillén, M.F. (1997). Scientific Management's lost aesthetic: Architecture, organization, and the Taylorized beauty of the mechanical. Administrative Science Quarterly, 42, 682-715.

Hassan, I. (1987). Pluralism in postmodern perspective. In M. Calinescu \& D. Fokkema (Eds.), Exploring postmodernism: Selected papers presented at a workshop on postmodernism at the XIth International Comparative Literature Congress. Amsterdam: John Benjamins Publishing Company.

Hassard, J. (1993). Sociology and organization theory: Positivism, paradigms and postmodernity. Cambridge: Cambridge University Press.

Holbrook, M.B. (1997). Feline consumption: Ethnography, felologies and unobtrusive participation in the life of a cat. European Journal of Marketing, 31 (3/4), 214-233.

Holbrook, M.B. (1998). Stereo 3D representations in postmodern marketing research. Marketing Intelligence \& Planning, 16 (5), 298-310.

Joyce, P., \& Woods, A. (1996). Essential strategic management: From modernism to pragmatism. Oxford: Butterworth-Heinemann.

Kacen, J.J. (2000). Girrrl power and boyyy nature: the past, present and paradisal future of consumer gender identity. Marketing Intelligence and Planning, 18 (6/7), 345-355.

Kilduff, M., \& Mehra, A. (1997). Postmodernism and organisational research. Academy of Management Review, 22 (2), 453 (29p). Available from EBSCO Host: http//www.search.epnet.com AN 9707154066 (Accessed 20/09/2001). Password required.

Kupiec, B., \& Revell, B. (1998). Speciality and artisanal cheese today: The product and the consumer. British Food Journal, 100 (5), 236-243.

Lash, A. (1990). Sociology of post modernism. London: Routledge.

Malina, D., \& Schmidt, R.A. (1997). It's business doing pleasure with you: Sh! A women's sex shop case. Marketing Intelligence \& Planning, 15 (7), 352-360.

MapActive (2000). E-Business. Breakfast briefing. Gallo Manor, Johannesburg.

Merrick, B. (2001). Move over, generation X. Credit Union Magazine, 67 (9), 18 (2/3p). Available: EBSCO Host: http://www-sa.ebsco.com/home/default.asp/. AN 5196004 (Accessed 20/05/2002). Password required.

Pascale, R., Millemann, M., \& Gioja, L. (1997). Changing the way we change (organisational change). Harvard Business Review, 75 (6), 126-139.

Power, M. (1990). Modernism, postmodernism and organization. In J. Hassard \& D. Pym (Eds.), The theory and philosophy of organizations: Critical issues and new perspectives. London: Routledge.
Reid, R., \& Brown, S. (1996). I hate shopping! An introspective perspective. International Journal of Retail \& Distribution Management, 24 (4), 4-16.

Robbins, A. (2002). Lessons in Mastery. Simon \& Schuster Incorporated. Audio cassette.

Ross, J.A. (1997). Does shuffling the deck work? (effectiveness of corporate reorganisation). Harvard Business Review, 75 (6), 17-18.

Rousseau, D. (1990). Personality and psychographics. In P.J. Du Plessis (Ed.), Consumer behaviour: A South African Perspective. Halfway House: Southern Book Publishers.

Silver, D. (1999). All consuming. Restaurants \& Institutions, 109 (34), 40 (6p). Available: EBSCO Host: http://wwwsa.ebsco.com/home/default.asp/. AN 2595236 (Accessed 20/05/2002). Password required.

Strinati, D. (1993). The big nothing? Contemporary culture and the emergence of postmodernism. The European Journal of Social Science, 6 (3), 359-375.

Sturrock, F., \& Pioch, E. (1998). Making himself attractive: The growing consumption of grooming products. Marketing Intelligence \& Planning, 16 (5), 337-343.

Takala, T. (1999). Business and leadership ethics conference three current themes. Leadership \& Organization Development Journal, 20 (7), 360-364.

Thomas, M.J. (1994). Marketing - in chaos or transition. European Journal of Marketing, 28 (3), 55-62.

Thomas, M.J. (1997). Consumer market research: Does it have validity? Some postmodern thoughts. Marketing Intelligence \& Planning, 15 (2), 54-59.

Tybout, A.M., \& Artz, N. (1994). Consumer Psychology. Annual Review of Psychology, 45, 131-169.

Van Tonder, C.L. (1999). Organisation identity: An exploratory study. Unpublished doctoral dissertation, Rand Afrikaans University, Johannesburg.

Varley, P., \& Crowther, G. (1998). Performance and the service encounter: An exploration of narrative expectations and relationship management in the outdoor leisure market. Marketing Intelligence \& Planning, 16 (5), 311-317.

Walsh, K. (1992). The representation of the past: Museums and heritage in the post modern world. London: Routledge.

Washburn, E.T.R. (2000). The five generations. Physician Executive, 26 (1), 54 (1p). Available: EBSCO Host: http://www-sa.ebsco.com/home/default.asp/. AN 2794580 (Accessed 20/05/2002). Password required.

Wood, E.M. (1996). Modernity, postmodernity, or capitalism? Monthly Review: An Independent Socialist Magazine, 48 (3). Available at: http://www.global.factiva.com/en/arch.asp (Accessed 09/10/2002). Password required.

Woodruff, R.B. (1997). Customer value: The next source for competitive advantage. Journal of the Academy of Marketing Science, 25 (2), 139-153.

Woodruffe-Burton, H. (1998). Private desires, public display: Consumption, postmodernism and fashion's "new man". International Journal of Retail \& Distribution Management, 26 (8), 301-310.

Young, S., \& Gautier, A. (2001). Champagne hopes on a beer CV. NZ Marketing Magazine, 20 (11), 10 (6p). Available: EBSCO Host: http://www-sa.ebsco.com/home/default.asp/. AN 5739955 (Accessed 20/05/2002). Password required. 